\title{
EU COMPETITION LAW IN THE DIGITAL ERA: ALGORITHMIC COLLUSION AS A REGULATORY CHALLENGE*
}

\author{
Ana Pošćić, PhD, Associate Professor \\ University of Rijeka, Faculty of Law and Inter-University \\ Centre of Excellence Opatija \\ Head of Department of European Public Law \\ Hahlić 6, HR-51000 Rijeka, Croatia \\ aposcic@pravri.hr
}

\author{
Adrijana Martinović, PhD, Assistant Professor \\ University of Rijeka, Faculty of Law and Inter-University \\ Centre of Excellence Opatija \\ Department of European Public Law \\ Hahlić 6, HR-51000 Rijeka, Croatia \\ adrijana@pravri.hr
}

\begin{abstract}
Guaranteeing fair competition has been a guiding principle of Union action since the beginnings of the European Economic Community. Anti-competitive activities in the internal market, such as agreements between undertakings, decisions by associations of undertakings and concerted practices which may affect trade between Member States and which have as their object or effect the prevention, restriction or distortion of competition, or abuse by one or more undertakings of a dominant position are probibited as incompatible with the internal market. Over the years, a vast body of regulatory and soft law instruments, as well as the Commission's decisions and the case law of the Court of Justice of the European Union have built up to handle a variety of complex issues associated with creating a level-playing field for undertakings in the internal market.
\end{abstract}

This work has been fully supported by the University of Rijeka under the project uniri-drustv-18-252 "Legal aspects of the digital transformation of society" 
As more and more businesses are using smart solutions, predictive analytics and algorithms for optimisation of their business processes, new business models and decision-making processes emerge. The development and use of self-learning machines, capable of intelligent behaviour in the market are changing the competitive landscape and market structure, thus generating many new and complex legal issues.

This paper aims to address the regulatory challenges associated with algorithmic collusion, as a form of anti-competitive behaviour among competing undertakings which is rarely manifested in explicit or even implied agreements. The issue of recognising and proving, and eventually, sanctioning tacit collusion practices becomes even more complicated when innovative digital technologies, such as implementation of price programming or self-learning algorithms enter the scene and rearrange the market structure. It is extremely difficult to differentiate between the situations in which undertakings adapt their strategies in response to the behaviour of their competitors from those where they change the interaction patterns altogether, by facilitating either conscious or unconscious parallel behaviour.

Is such behaviour caught by Article 101 of the Treaty on the Functioning of the European Union? What kind of regulatory response, if any, is needed? The authors will analyse the existing practice on tacit collusions, developed in the era of 'brick and mortar' economy and evaluate whether a new framework is needed in the digital era. Is hard regulation suitable, or desirable at all, or could these challenges be addressed through a set of guidelines or soft law instruments? The technology is evolving faster than any legal framework. Without first knowing and understanding how algorithms work, it is impossible to develop an appropriate response to these issues. The authors offer their contribution to this on-going debate.

Keywords: EU competition law, pricing algorithms, tacit collusion, parallel behaviour

\section{INTRODUCTORY REMARKS}

Businesses rely on different tools to increase their efficiency and competitiveness. Advanced technologies and the use of complex algorithms enable processing of enormous amounts of data, their analysis and recognition of new trends at an incredible speed, allowing for immediate reaction and faster adaptation to changing market conditions. ${ }^{1}$ Predictive analytics and optimisation of business processes as legitimate market strategies have taken a whole new dimension in the digital age and the algorithm-driven business world. Algorithmic business implies the use of complex algorithms to improve business decisions and automatise processes for competitive differentiation. ${ }^{2}$ Pricing algorithms are especially important tools for monitoring and adapting to competition. Two-thirds of online retailers in the EU use pricing software programmes that autonomously adjust their prices based on

1 Krausová, A., EU Competition Law and Artificial Intelligence: Reflections on Antitrust and Consumer Protection Issues, The Lawyer Quarterly, vol. 9, no. 1/19, p. 79

2 Ezrachi, A.; Stucke, M. E., Virtual Competition: The Promise and the Perils of the Algorithm-Driven Economy, Harvard University Press, Harvard, 2016. See also OECD, Algorithms and Collusion: Competition Policy in the Digital Age, 2017, p. 11 [http://www.oecd.org/daf/competition/Algorithms-and-colllusion-competition-policy-in-the-digital-age.pdf], accessed 02. May 2020 
the observed prices of competitors. ${ }^{3}$ Although pricing algorithms are not novel, ${ }^{4}$ with improved technological solutions they have become increasingly sophisticated, providing for real-time automated pricing decisions. Their wide scale use may lead to price coordination and anticompetitive effects. ${ }^{5}$

The risk of tacit collusion increases with the growing number of competitors using sophisticated pricing algorithms. ${ }^{6}$ Algorithms can bring us closer to the perfect competition model. ${ }^{7}$ There is less need for mutual communication. ${ }^{8}$ Algorithms provide the possibility to coordinate strategic decisions and future market practices, even without human intervention.

At what point can legitimate algorithmic business become algorithmic collusion? Is algorithmic collusion even possible, and if it is, how can it be recognised, proven and sanctioned?

The usual metaphor for collusion is that of CEOs meeting in smoke-filled rooms to discuss market conditions for their products and services or just to exchange commercially sensitive information which they will later use to adapt their business strategies. This may result in price-fixing, market-sharing and/or customer allocation, or any other example of creating artificial market conditions to increase profitability and facilitate company gains, which would otherwise not be possible or would not be possible in such extent. These types of activities were always around, and the competition law has developed efficient mechanisms to sanction

3 European Commission, Final Report on the E-Commerce Sector Inquiry, COM(2017) 229 final, Brussels, 10.5.2017, p. 5

4 British Airways seems to have been the first company to use pricing algorithms in the 1970s. See Calvano, E. et al., Algorithmic Pricing: What Implications for Competition Policy?, Review of Industrial Organization, vol. 55, no. 1, 2019, pp. 155-171, p. 155; McAfee, R.P.; te Velde, V., Dynamic Pricing in the Airline Industry, [https://mcafee.cc/Papers/PDF/DynamicPriceDiscrimination.pdf], accessed 02. May 2020. For an account of algorithm pricing and trading in the financial industry, see Mehra, S. K., Antitrust and the Robo-Seller: Competition in the Time of Algorithms, Minnesota Law Review, vol. 100, 2016, pp. 1323-1375

5 "With pricing software, detecting deviations from 'recommended' retail prices takes a matter of seconds and manufacturers are increasingly able to monitor and influence retailers' price setting. The availability of real-time pricing information may also trigger automatised price coordination. The wide-scale use of such software may in some situations, depending on the market conditions, raise competition concerns." European Commission, Final Report on the E-Commerce Sector Inquiry, note 3, p. 5

6 Ezrachi, A.; Stucke, M. E., Artificial Intelligence \& Collusion: When Computers Inhibit Competition, University of Illinois Law Review, vol. 2017, no. 5, 2017, pp. 1775 - 1810, p. 1778

7 See more on this issue in Pošćić, A., Europsko pravo tržišnog natjecanja i interesi potrošača, Narodne Novine, Zagreb, 2014, pp. 47 and 48

8 Baker, J., The Antitrust Paradigm, Restoring a Competitive Economy, Harvard University Press, Cambridge, London, 2019, p. 99 
them. However, this metaphor for collusion has become obsolete, not just due to the smoking ban. Why meet in person, when the meeting can take place in the virtual world? Actually, why meet at all? The digital environment provides ample opportunities to achieve the same anticompetitive effects, through tacit collusive practices or "conscious parallelism". ${ }^{9}$ Many of such practices remain undetected or unsanctioned by the existing mechanisms for the protection of competition, because they are currently outside of their scope.

In order to decide whether additional regulatory action is needed, it is necessary to have at least a basic understanding of how algorithms work.

\section{THE ROLE AND IMPACT OF ALGORITHMS IN COMPETITION}

What role and impact do algorithms have in competition policy? The answer depends on the type and features of algorithms. Not all algorithms operate in the same manner.

In the most general terms, algorithms refer to an unambiguous and precise list of logic instructions applied systematically and mechanically to carry out a certain task, i.e. generate an output from a given input. ${ }^{10}$ Digital algorithms represent a sequence of computational steps that transform the input into output. ${ }^{11}$ They are usually differed according to the tasks they perform (e.g. monitoring and data collection algorithms, pricing algorithms, price tracking algorithms, algorithms for personalisation, ranking, etc.), input parameters (i.e. technical variables such as data size, type or level of detail), methods of learning they rely on (fixed and machine learning ${ }^{12}$ algorithms) or their interpretability (e.g. white box or descriptive and black box algorithms). ${ }^{13}$

Pricing algorithms can be implemented through more or less complex systems which apply one or more algorithms simultaneously, where input - output values

$9 \quad$ Ezrachi, A.; Stucke, M. E., Sustainable and Unchallenged Algorithmic Tacit Collusion, Northwestern Journal of Technology and Intellectual Property, vol. 17, issue 2, 2020, pp. 217-260, pp. 218, 224

10 OECD, op. cit., note 2, p. 8, citing Wilson, R. A.; Keil, F. C., The MIT Encyclopedia of Cognitive Sciences, MIT Press, 1999. There is no single universally accepted definition, but algorithms are applicable in all spheres of human existence

11 Cormen, T. H. et al., Introduction to Algorithms, $3^{\text {rd }}$ Ed., The MIT Press, Cambridge, London, 2009, p. 9; Bundeskartellamt, Autorité de la Concurrence, Algorithms and Competition, 2019, p. 3, [https:// www.bundeskartellamt.de/SharedDocs/Publikation/EN/Berichte/Algorithms_and_Competition_ Working-Paper.pdf?_blob=publicationFile\&v=5], accessed 02. May 2020

12 Also known as self-learning

13 For an overview of typology of algorithms see Bundeskartellamt, Autorité de la Concurrence, op. cit., note 11, p. 4 and further. According to the roles of algorithms in implementing collusion, there are monitoring, parallel, signalling and self-learning algorithms. See OECD, op. cit., note 2, pp. 25-32 
can be programmed in a deterministic or probabilistic manner. ${ }^{14}$ The increased use of self-learning or machine learning algorithms is the most challenging from the competition law perspective. Depending on the learning patterns applied, machine learning includes supervised, unsupervised and reinforcement learning. ${ }^{15}$ Not just the pattern, but also the frequency of learning is important: whether it involves a continuous exercise or just initial training. ${ }^{16}$ In addition, the degree of interpretability cannot be overestimated. Traditional machine learning algorithms are linear and descriptive. On the other hand, deep learning algorithms are structured in a hierarchy of increasing complexity and abstraction. ${ }^{17}$ They rely on neural networks, mimicking the human brain. ${ }^{18}$

The use of self-learning algorithms is the basis of artificial intelligence. Artificial intelligence (AI) is usually explained as the art of "making intelligent machines". ${ }^{19}$ $\mathrm{AI}$ is actually a collection of technologies that combine data, algorithms and computing power. ${ }^{20}$ For algorithms to work, they need to be fed with enormous amounts of data. Sometimes, raw data has to be "engineered" to extract the relevant input features, which the algorithm will be able to process to make sense out of. ${ }^{21}$ When deep learning is used for feature extraction, there is a risk of obfuscation, i.e. there is no way of recognizing or recreating how the machine really reached its decision. ${ }^{22}$ Self-learning algorithms internalize that data, and are able to make dynamic decisions "experientially or intuitively like humans", finding "solutions to problems based on patterns in data that humans may not even be

14 Monopolkommission, Wettbewerb 2018. XXII. Hauptgutachten der Monopolkommission gemäß $\$$ 44 Abs. 1 Satz 1 GWB, para. 169 and further, [https://www.monopolkommission.de/images/HG22/ HGXXII_Gesamt.pdf], accessed 02. May 2020

15 These are typical categories, with many subcategories. In brief, supervised learning involves typical input-output pairs; unsupervised learning involves identification of anomalies and hidden structures from unlabelled data, while reinforcement learning means that an algorithm performs a task in a dynamic environment and learns through trial and error. See OECD, op. cit., note 2, p. 9; Bundeskartellamt, Autorité de la Concurrence, op. cit., note 11, p. 10

16 Bundeskartellamt, Autorité de la Concurrence, ibid., p. 11

17 OECD, op. cit., note 2, p. 11

18 Bundeskartellamt, Autorité de la Concurrence, op. cit., note 11, p. 12

19 OECD, op. cit., note 2, p. 9

20 European Commission, White Paper on Artificial Intelligence - A European approach to excellence and trust, $\operatorname{COM}(2020) 65$ final, Brussels, 19.2.2020., p. 2. AI systems, whether they are purely software-based or embedded in hardware devices, display intelligent behaviour by analysing their environment and taking actions, with some degree of autonomy, to achieve specific goals. See European Commission, Artificial Intelligence for Europe, COM(2018) 237 final, Brussels, 25.4.2018, p. 1

21 OECD, op. cit., note 2, p. 9

22 Ibid., p. 11 
able to perceive". ${ }^{23}$ Self-learning algorithms based on deep learning are often referred to as the so-called "black box" algorithms, ${ }^{24}$ as their operation may be incomprehensible, inexplicable and impossible to interpret, even to their creators. ${ }^{25}$ This could serve as convenient argument for economic operators to "hide behind the computer program" ${ }^{26}$ It also reminds us that, although there are humans behind the algorithms, legal doctrines which are focused on human conduct, such as intent, may have a very limited effect on AI self-learning algorithms. ${ }^{27}$

Dynamic pricing based on complex algorithms has been around for decades, especially in passenger air transport and accommodation..$^{28}$ It is the typical example of algorithmic business. ${ }^{29}$ However, with the development of artificial intelligence, machine learning and deep learning models, dynamic pricing is taken to the next level of tacit collusion and price-fixing with potentially harmful effects on competition. Take the example of surge pricing in the business model of Uber. The base rate of ride is calculated by an algorithm, based on the time and distance of a trip (a flat fee might be added in certain areas to "support operational, regulatory, and safety costs"). ${ }^{30}$ However, the algorithm monitors the level of demand, so that

23 Bathaee, Y., The Artificial Intelligence Black Box and the Failure of Intent and Causation, Harvard Journal of Law \& Technology, vol. 31, no. 2, 2018, pp. 890-938, p. 891. For a further explanation of the problems associated with understanding how artificial neural networks reach their decisions see Castelvecchi, D., The Black Box of AI, Nature, vol. 538, 2016, pp. 20-23

24 "The black box metaphor dates back to the early days of cybernetics and behaviourism, and typically refers to a system for which we can only observe the inputs and outputs, but not the internal workings." Card, Dallas, The "Black Box" Metaphor in Machine Learning, 2017, [https://towardsdatascience. com/the-black-box-metaphor-in-machine-learning-4e57a3a1d2b0], accessed 02. May 2020

25 Bathaee, op. cit., note 23, p. $891 \mathrm{ff}$.

26 Vestager, M., Algorithms and competition, speech, Bundeskartellamt 18th Conference on Competition, Berlin, 16 March 2017 [https://ec.europa.eu/commission/commissioners/2014-2019/vestager/announcements/bundeskartellamt-18th-conference-competition-berlin-16-march-2017_en], accessed 20. June 2020

27 Bathaee, op. cit., note 23, p. $890 \mathrm{ff}$.

28 McAfee; te Velde, op. cit., note 4

29 Pricing decisions may depend on the input and output of many complex algorithms. For example, all airlines rely on dynamic demand forecasting as part of their pricing strategies, which implies tactical balancing of supply, demand and pricing, as well as updating forecast ticket sales for each flight. Accurate forecasts depend on availability of data, as well as on the improvement in probabilistic programming and application of machine learning techniques. For an explanation how this works in practice, see for example the information on the UK's Alan Turing Institute collaboration with the British Airways in developing a dynamic demand forecasting algorithm, with input including data on daily ticket sales for approximately one million flights from the previous three years (six billion rows of data, with a complex time-series structure), but also other "existing knowledge, recent trends and new data when available", [https://www.turing.ac.uk/research/impact-stories/dynamic-forecasting-british-airways], accessed 02. May 2020. Advances in data science and artificial intelligence should not be overlooked or underestimated when competition law aspects are at stake

30 Uber [https://www.uber.com/us/en/price-estimate/], accessed 02. May 2020 
when there are more riders than available drivers, prices may temporarily increase "until the marketplace is rebalanced". ${ }^{31}$ The algorithm, therefore, automatically eliminates any price competition among drivers and has negative effects on demand. ${ }^{32}$ Still, similar algorithms are essential part of a business model of many companies in the platform economy.

According to Ezrachi and Stucke, pricing algorithms raise particular competition concerns, as they can either help competitors elude detection for their price-fixing, or can act as agents of collusion themselves, with or without human intervention. ${ }^{33}$ In the latter case, especially where there is no human intervention, it is hard to accept that algorithms themselves can tacitly collude. This is why some authors refer to it as a "legal sci-fi". ${ }^{4}$ The concept of tacit collusion or conscious parallelism is well known in competition law. It may occur under certain market circumstances (oligopolistic concentrated markets) in which competitors rationally adjust their market behaviour without any communications. ${ }^{35}$ Given that conscious parallelism between undertakings is not unlawful by itself, but nevertheless may result in collusive outcomes, it is not surprising that the implication of algorithms brings additional challenges.

31 Loc. cit.

32 Uber's surge pricing was challenged in the United States in 2016 by a customer, who filed a civil antitrust suit against the Uber's CEO and founder Travis Kalanick for organising a horizontal price-fixing arrangement, which was explicitly recognised as a plausible allegation of a "hub and spoke" cartel in the Judge Rakoff's Opinion denying the defendant's motion to dismiss. See Spencer Meyer v. Travis Kalanick, 15 Civ. 9796, US District Court, Southern District of New York, Opinion and Order of 31 March 2016. This case was eventually compelled to arbitration and did not proceed to trial. See, Spencer Meyer v. Travis Kalanick and Uber Technologies Inc., 15 Civ. 9796, Opinion and Order of 5 March 2018

33 Ezrachi; Stucke, op. cit. note 9, p. 218

34 Schwalbe offers an overview of computer science and economic literature in support of this view. See Schwalbe, U., Algorithms, Machine Learning, and Collusion, Journal of Competition Law \& Economics, vol. 14, issue 4, 2018, pp. 568-607, available at SSRN [https://ssrn.com/abstract=3232631] or [http://dx.doi.org/10.2139/ssrn.3232631], accessed 25. June 2020

35 Ibid., p. 232, citing one US Supreme Court decision: „Tacit collusion, sometimes galled oligopolistic price coordination or conscious parallelism, describes the process, not in itself unlawful, by which firms in a concentrated market might in effect share monopoly power, setting their prices at a profit-maximizing, supracompetitive level by recognizing their shared economic interests and their interdependence with respect to price and output decisions." Brooke Group v. Brown \& Williamson Tobacco Corp., 509 U.S. 209, 227 (1993) 


\section{AI, ALGORITHMS AND COLLUSION}

\subsection{From parallel behaviour to algorithmic collusion}

Competition policy and law may not be designed or ready to deal with all the challenges associated with algorithmic business. That does not stop the AI and self-learning algorithms from transforming competition. Economic theory suggests that there is a considerable risk that algorithms, by improving market transparency and enabling high-frequency trading, increase the likelihood of collusion in market structures that would traditionally be characterised by fierce competition. ${ }^{36}$ Especially in the context of price-fixing, intelligent systems have an ability to learn from their surrounding and develop response strategies to achieve their goals in unpredictable ways. These types of algorithms are deep learning or second-generation pricing algorithms. ${ }^{37}$ They facilitate parallel behaviour of competitors and thus increase a risk of achieving collusive results, ${ }^{38}$ without being caught by competition rules as they currently stand.

In other words, collusion has relocated to digital surroundings. Now, it is facilitated by technology: algorithms and artificial intelligence. Machines are far better and faster at collecting, processing and exchanging information. Exchange of information is vital for collusion. As is the existence of some form of conscious behaviour in the form of direct or indirect contact. The problem is, that with the use of new advanced information technologies and machine learning techniques, economic operators may not have been consciously involved in some kind of collusion, or at least that is what they claim. The algorithm may replace the competitors' intent and facilitate collusive parallel behaviour, which makes the conclusion of cartel agreements or concerted practices superfluous. ${ }^{39}$ With tacit collusion or conscious parallelism competitors unilaterally raise prices above competitive level in response to the behaviour of their rivals, but without "any illegal agreement or even any contact or communication among the competitors". ${ }^{40}$ This type of paral-

OECD, op. cit., note 2, p. 7

Calvano et al., op. cit., note 4, p. 331

Ezrachi; Stucke, op. cit., note 9, p. $242-244$

39 The German Monopolkommission has analysed the impact of pricing algorithms on collusion and has warned that their increased use in the future will lead to more pronounced negative effects on consumers, as it will be easier to achieve the same collusive effects even without actual agreements or concerted practices. Moreover, in the case of self-learning algorithms, the relevant business decision is already made at the time of the decision regarding the price algorithm and is not made in the price-setting process. See Monopolkommission, op. cit, note 14, para. 228 and 230

40 Ezrachi; Stucke, op. cit., note 9, p. 218, 224 
lel behaviour may lead to anticompetitive outcomes, which cannot be challenged or sanctioned. ${ }^{41}$

\subsection{Communicating by algorithms: theoretical and practical underpinnings}

Despite the interest of the European Commission ${ }^{42}$ and national competition authorities ${ }^{43}$ potential cases of algorithmic collusion are very rare. In the United States, the most prominent cases to date involve rather obscure algorithmic collusion for the sale of posters on Amazon. In the first case, ${ }^{44}$ an online retailer selling classic cinema posters on Amazon pleaded guilty for orchestrating a collusion through the use of price-fixing algorithm which kept the prices artificially high. A similar collusive price-fixing scheme was at stake in the second case before the U.S. District Court of Northern California, ${ }^{45}$ where the defendants were sentenced for using commercially available algorithm-based pricing software to set the prices of agreed-upon posters sold on Amazon Marketplace. This software operated by collecting competitor pricing information for a specific product sold on Amazon Marketplace and applying pricing rules set by the seller. However, both of these cases involved contacts or some sort of communication between competitors, and the algorithm was a tool for implementing that agreement. This is known as the "Messenger" scenario, where computers are used as tools which facilitate illicit agreements. ${ }^{46}$ From antitrust perspective, it should not be too demanding to prove the existence of a cartel in such situations, since it implies some sort of communication between competitors, not least because they are the ones who control computers and manners of their use. ${ }^{47}$ Algorithms are just a tool in executing the will of their creators, ${ }^{48}$ whether they are used to implement the existing agreement or to monitor and sanction deviant behaviour. ${ }^{49}$ Another scenario where algo-

$41 \quad$ "The courts and agencies accept that tacit collusion is not only legal, but likely and sustainable in concentrated industries. Absent proof of an agreement, the plaintiff cannot challenge the anticompetitive conduct." Ezrachi; Stucke, ibid., p. 236, see also Kaplow, L., Competition Policy and Price Fixing, Princeton University Press, 2013

42 See, e.g. European Commission, Competition policy for the digital era, A Report by Crémer, J., de Montjoye, Y. - A., Schweitzer, H., 2019, [https://ec.europa.eu/competition/publications/reports/ kd0419345enn.pdf], accessed 02. May 2020

43 See Monopolkommission, op. cit, note 14; Bundeskartellamt, Autorité de la Concurrence, op. cit., note 11

44 U.S. v. David Topkins, U.S. District Court, Northern District of California, No. 15-cr-00201

45 U.S. v. Daniel William Aston and TROD Ltd., CR 15 419, US District Court, Northern District of California

46 Ezrachi; Stucke, op. cit., note 2; Ezrachi; Stucke, op. cit., note 9, p. 219

47 Ezrachi; Stucke, op. cit., note 2, p. 39

48 Ibid., p. 45

49 See Monopolkommission, op. cit, note 14, para. 186 
rithms are used as tools and can significantly facilitate collusion is the so-called "Signalling", where competitors raise their prices as a signal for other competitors to follow. ${ }^{50}$

Collusion is also possible through the parallel use of the same algorithm, in markets where many competitors use similar or same algorithms. ${ }^{51}$ Ezrachi and Stucke refer to the "Hub and Spoke" scenario, which implies that one central algorithm is determining the price applied by many competitors, which generates market changes. ${ }^{52}$ Competitors use the common algorithm which may lead to horizontal concertation i.e. mutual dependence and awareness of the fact that the overall results will depend on the joint success of the hub. Regulators will have to determine, if it is possible, whether the algorithm is programmed in the manner which will facilitate the implementation of the agreement. Thus, algorithm is used to stabilise prices and decrease the usual insecurities in the market. It is important to show whether there is an intent to achieve prohibited conduct, i.e. if competitors act with knowledge about the potential prohibited conduct. If algorithm is used to facilitate collusion, the situation is identical to the first scenario.

In order to establish the existence of a cartel under the "Hub and Spoke" scenario, the authorities will have to show that competitors willingly entered into such arrangements, or that the possible anticompetitive effects are known to them. This scenario clearly shows the challenges faced by the regulators. The Commission considers that concerted practice is manifested in the moment of exchange of information among competitors. Cartels can occur in markets where computers organise and control the exchange of information about prices, although there was no initial intent of the competitor to enter into prohibited agreements. Subjective concepts, such as intent, are very difficult to export and bring into the digital surrounding. Thomas suggests that instead of relying on intent, consumer harm should be used as a reliable and workable external standard for distinguishing between illicit collusion and legitimate oligopoly conduct where algorithms and machine learning is involved. ${ }^{53}$ This would imply integrating the economic effects analysis into the notion of concerted practices. ${ }^{54}$

\footnotetext{
$50 \quad$ Ibid., para. $187-188$

51 Ibid., para. 189-190. Ezrachi; Stucke, op. cit., note 6, p. 1788

52 Ezrachi; Stucke, op. cit., note 2, p. 46. It is named after a bicycle wheel with strong central hub and many spokes

53 Thomas, S., Harmful Signals - Cartel Prohibition and Oligopoly Theory in the Age of Machine Learning, Journal of Competition Law \& Economics, vol. 15, issue 2-3, June/September 2019, pp. 159_ 203; available also at SSRN [https://ssrn.com/abstract=3392860] or [http://dx.doi.org/10.2139/ ssrn.3392860], p. 22 et seq., accessed 25. June 2020

54 Ibid., p. 27
} 


\subsubsection{The Eturas case: business as usual?}

There is a long way from theory to practice, as illustrated by the current approach of the Court of Justice of the EU (hereinafter: CJEU). Case Eturas ${ }^{55}$ was the first one in which the CJEU examined the application of automated systems in competition. It concerned 30 travel agencies in Lithuania, which used an on-line booking system for organised tours (E-TURAS), owned by the agency Eturas. Eturas has programmed the $3 \%$ upper limit of discount to automatically apply for organised tours booked through the system and informed all of its business partners (30 travel agencies) about it. The CJEU determined that the on-line booking system enabled concertation without the need for direct contact between Eturas and other agencies. They have never publicly expressed their reservation or distanced themselves from such practice, which suffices to establish the existence of a strong presumption of their tacit consent to such conduct in the relevant market. ${ }^{56}$ The agencies have argued that the conduct of Eturas was unilateral, as there was neither will nor intent on their part to conclude such agreement. The CJEU stressed that the concentration cannot be inferred from the existence of a technical restriction imposed by the platform unless it is established on the basis of other objective evidence that it tacitly assented to anticompetitive practice. ${ }^{57}$ It means that only those agencies that were aware of the practice could be held liable of infringement. The CJEU established a presumption of concertation applying the standard criteria developed in its settled case law, but has nevertheless allowed the possibility for competitors to rebut that presumption, in accordance with the national rules relating to the assessment of evidence and the standard of proof..$^{58}$ Apart from public distancing or reporting to the authorities, the CJEU confirmed the possibility of offering "other evidence" by competitors with a view to rebutting that presump-

55 Case C-74/14 Eturas UAB and Others v. Lietuvos Respublikos konkurencijos taryba, EU:C:2016:42

56 Ibid., para. 15

57 Ibid., para. 45

58 "Article 101(1) TFEU must be interpreted as meaning that, where the administrator of an information system, intended to enable travel agencies to sell travel packages on their websites using a uniform booking method, sends to those economic operators, via a personal electronic mailbox, a message informing them that the discounts on products sold through that system will henceforth be capped and, following the dissemination of that message, the system in question undergoes the technical modifications necessary to implement that measure, those economic operators may - if they were aware of that message — be presumed to have participated in a concerted practice within the meaning of that provision, unless they publicly distanced themselves from that practice, reported it to the administrative authorities or adduce other evidence to rebut that presumption, such as evidence of the systematic application of a discount exceeding the cap in question." (C-74/14, Judgment, Operative part, para. 1). For a case commentary see also Heinemann, A.; Gebicka, A., Can Computers Form Cartels? About the Need for European Institutions to Reverse the Concertation Doctrine in the Information Age, Journal of European Competition Law \& Practice, vol. 7, no. 7/16, p. 434 ff. 
tion. ${ }^{59}$ It did not, however, explain what that other evidence may be, taking into account the specific circumstances involving the use of new technology.

What the Court probably wanted to highlight is that the technology by itself is not capable of infringing competition. A certain communication and consent of participants needs to be established. This situation clearly points to the need to adapt competition law to new circumstances. As Gal rightly points out, advances in machine learning allow algorithms to automatically discover and create the communication protocols needed to coordinate their behaviour. ${ }^{60}$ Despite such theoretical possibility, the CJEU has followed its settled case law here, without giving special consideration to the fact that in this case, the use of computer programmes might have obviated the need to participate at meetings or it has at least made the collusion substantially easier. It should be kept in mind that the use of algorithms, in cases like this, can have certain advantages, for example, because it increases consumer welfare by improving the quality of services and decreasing the prices. ${ }^{61}$ From this perspective, algorithms are capable of stabilising the markets. ${ }^{62}$

\subsubsection{Fast forward: algorithms take the wheel}

What these two scenarios have in common is the proven presence of some human interaction in the collusion. More complicated are the 'real' cases of algorithmic tacit collusion, where no human interaction is needed. ${ }^{63}$ Ezrachi and Stucke identify two additional scenarios where algorithms meet competition law, which are much more controversial in terms of developing novel policy and regulatory approaches: the so-called "Tacit collusion on steroids" (or "Predictable Agent" 64 scenario) and "AI and the Digital Eye". ${ }^{65}$ In these two scenarios, no human interaction is needed: "the self-learning algorithms may independently arrive at tacit

59 Case C-74/14 Eturas UAB and Others v. Lietuvos Respublikos konkurencijos taryba, EU:C:2016:42, para. 46

60 See Gal, M., Algorithms as Illegal Agreements, Berkeley Technology Law Journal vol. 34, 2019, pp. 67-118 [https://btlj.org/data/articles2019/34_1/02_Gal_Web.pdf], p. 87 and especially literature referred in fn. 95, accessed 25. June 2020. As Gal succinctly puts it, "The algorithm can communicate much more than price choice: it communicates a business strategy"

${ }_{61}$ On pro-competitive algorithmic efficiencies see more in OECD, op. cit., note 2, pp. 15 - 18; Lee, K., Algorithmic Collusion \& Its Implication for Competition Law and Policy, 2018, pp. 15 - 16, [https://ssrn. com/abstract=3213296], accessed 02. May 2020

62 See, e.g. Mehra, op. cit., note 4, p. 1373

63 Mehra discusses about the anti-trust law's "randezvous with the robo-seller" and the question "Can robo-sellers really rase prices?” ibid., pp. 1323-1375

64 Ezrachi; Stucke, op. cit., note 6, p. 1789

${ }_{65}$ Ezrachi, Stucke, op. cit., note 9, p. 220 
collusion, without the knowledge or intent of their human programmers" ${ }^{66}$ In the scenario of "Tacit collusion on steroids" the competitors use algorithms capable of predicting future behaviour and promptly reacting in accordance with changed market conditions. Each operator develops its own programme, knowing that other developers are developing their own algorithms individually. ${ }^{67}$ There is no agreement here, ${ }^{68}$ neither horizontal nor vertical. Predictability and market transparency are crucial. Thanks to available information, parallel conduct by competitors is facilitated, which is not prohibited because it represents adjustment to changed market conditions. The use of sophisticated model changes market dynamic and stimulates conscious parallel behaviour. Similar to the previous two scenarios, none of the competitors has taken part in some sort of an arrangement. The competitor is just encouraged to achieve its economic interest. It is still debated in theory whether these situations should fall under conscious parallel behaviour. Parallel behaviour is not prohibited, even if it is questionable whether it should be acceptable. Regulators might encounter situations in which the increase in prices is not part of express agreement, but an immediate reaction to market circumstances. ${ }^{69}$ Sanctioning illicit agreements requires certain evidence, which are impossible to establish in this case. It seems that this could be the right way forward, because condemning every progress and use of super technology can diminish the motivation to develop new innovative models and future investment. ${ }^{70}$

The last scenario, "AI and the Digital Eye" ${ }^{71}$ is the most complex one, probably more in the realm of science fiction at this moment, but given the rapid development of new technologies, it will not be long before it becomes a reality.

Machines are programmed to accomplish certain objectives, mostly in the form of profit maximisation. It is impossible to speak about intent or certain form of agreement here. ${ }^{72}$ They apply algorithms to achieve programmed objectives. They

\footnotetext{
66 Ibid.

${ }_{67}$ Ezrachi; Stucke, op. cit., note 6, p. 1783

68 Ibid., p. 1790

69 As highlighted by Mehra "Robo-sellers should be more effective than humans at sussing out the right choice of quantity or price in the absence of explicit agreement or communications". See Mehra, $o p$. cit., note 4, p. 1346

70 Lawyers compare punishing companies for designing such technology with sentencing "a gun manufacturer for someone else committing a murder with a gun the manufacturer produced". See Zdzieborska, M., Brave New World of 'Robot' Cartels?, Kluwer Competition Law Blog, March 7, 2017, [http:// competitionlawblog.kluwercompetitionlaw.com/2017/03/07/brave-new-world-of-robot-cartels/], accessed 02. May 2020. Perhaps this comparison is overexaggerated, but it succinctly explains the regulation dilemma

71 Ezrachi; Stucke, op. cit., note 2, p. 71 ff

72 Ezrachi; Stucke, op. cit., note 6, p. 1783
} 
adapt to the data gathered and according to feedback received adapt their strategy. Mutual communication can lead to a certain form of collusion. ${ }^{73}$ Competition law regulates and controls mutual communication among competitors. It is questionable who is responsible in this case or whether machines can be controlled in the first place. These types of self-learning machines "are functionally black boxes to humans". ${ }^{74}$

\subsection{Regulatory challenges}

The crucial element for determining the existence of an agreement is missing. The persons developing the algorithms have no motive whatsoever to enter into a prohibited agreement. Competitors base their decisions on predictions provided by the self-learning machines, in this case, artificial intelligence. The machine has a purpose and acts autonomously to achieve it. One of its goals may be to increase transparency in the market and to maintain concealed parallel conduct. In this example, coordination is the result of development, self-learning and autonomous behaviour by the machine. ${ }^{75}$ Regulators should potentially examine whether prices enacted by smart machines in the digital surrounding should automatically be declared as prohibited conduct. With machines which adapt to new input and competitive scenarios very fast, users and developers may predict whether prices will be increased, but cannot predict when, for how long and in what ratio. ${ }^{76}$ It is easier for them to adapt to changed market conditions. If machines have no order to start a cartel, a legitimate question is whether they are able to enter into prohibited agreements. Lack of proof concerning anticompetitive intent can result in machines using artificial intelligence, i.e. their developers to avoid questions about the legality of agreements. The use of artificial neural networks can make examining previous pricing strategies even harder. The question is, whether the operation of machine can be discerned from the actions of its developer. In artificial intelligence, the machine is learning by itself and makes autonomous decisions based on the data it collected. ${ }^{77}$

73 Ezrachi; Stucke, op. cit., note 2, p. 74. See also Gal, op. cit., note 60, p. 106 et seq.; Ittoo, A.; Petit, N., Algorithmic Pricing Agents and Tacit Collusion: A Technological Perspective, in: Jacquemin, H.; De Streel, A. (eds.), L'intelligence artificielle et le droit, Bruxelles: Larcier, 2017, pp. 241-256. Available also at SSRN [https://ssrn.com/abstract=3046405] or [http://dx.doi.org/10.2139/ssrn.3046405], accessed 25. June 2020

74 Bathaee, op. cit., note 23, p. 938.

75 Ezrachi; Stucke, op. cit., note 2, p. 78

76 Loc. cit.

77 As noted by Beneke and Mackenrodt, artificial neural networks can perform this task well if there is enough data. Given the reliance on past data, tacit coordination by algorithms will be disrupted with radical industry changes, such as the introduction of new technologies or entry of new competitors. 
The German Monopolkommission has already proposed some possible solutions for these issues, which require legislative intervention, but are built on the presumption that these types of anticompetitive behaviour are better caught under Article 102 TFEU, because they imply unilateral behaviour by the economic operator. ${ }^{78}$ Such approach has its limits, primarily because it presupposes the existence of a dominant position in the relevant market, and its abuse. Another option for competition law to tackle these challenges is through merger control. Mergers may foster tacit collusion in general, because it does not require any communication or agreement between competitors. ${ }^{79}$

One of the first and foremost issues associated with the use of pricing algorithms is to properly identify suspicion of collusive behaviour. This entails identifying anomalies i.e. patterns which deviate from normal conditions in a relevant market in a certain time period. But what are normal conditions? Pricing algorithms are being used for a long time, but they are becoming more sophisticated in adapting or even creating artificial conditions to achieve their programmed objectives in extremely short periods of time. This means that competition authorities and other entities will have to use algorithms themselves to understand and detect potential collusive effects. Whistle-blowing incentives may work on humans, but not of algorithms ${ }^{80}$ But what is normal, if markets are already changed? Are we comparing anomalies with other anomalies, which have become the "new" normal as they have replaced normal market conditions long ago?

Another problem with algorithmic collusion is that it necessarily involves a third party - the creator or maker of algorithm, used within an application or a platform. This entails various issues regarding their liability for participation in a cartel.

How do these particularities fit into the existing regulatory framework?

See Beneke, F.; Mackenrodt, M., Artificial Intelligence and Collusion, International Review of Intellectual Property and Competition Law - IIC vol. 50, 2019, pp. 109-134, p. 127

78 Monopolkommission, op. cit., note 14, para. 217 - 224. See also Bundeskartellamt, Autorité de la Concurrence, op. cit., note 11, p. 25

79 Ezrachi, Stucke, op. cit., note 9, p. 233

80 Oxera, Algorithmic Competition, 2018, [https://ec.europa.eu/competition/information/digitisation_2018/contributions/oxera/oxera_algorithmic_competition.pdf], accessed 02. May 2020 


\section{IS THE EXISTING REGULATORY FRAMEWORK SUFFICIENT TO DEAL WITH ALGORITHMIC COLLUSION?}

\subsection{Revisiting the established concepts}

The law and principles of competition prescribed in Articles 101 and 102 of the Treaty on the Functioning of the $\mathrm{EU}^{81}$ (hereinafter: TFEU) and the case law arising therefrom is our main reference point for assessing the applicability and adaptability of the existing regulatory framework to the challenges arising from algorithm-driven markets.

Freedom of contract is the cornerstone of free markets. However, this freedom has its limits. Entering into agreements to artificially change conditions of free competition, by decreasing available products and increasing prices, is prohibited. ${ }^{82}$ Pursuant to Article 101(1) TFEU, all agreements between undertakings, decisions by associations of undertakings and concerted practices which may affect trade between Member States and which have as their object or effect the prevention, restriction or distortion of competition within the internal market are prohibited as incompatible with the internal market. ${ }^{83}$ The objective of Article 101 TFEU is to prohibit all forms of collusion among competitors, that could limit competition and affect trade between Member States. The definitions of 'agreement', 'decisions by associations of undertakings' and 'concerted practice' are intended, from a subjective point of view, to catch all forms of collusion having the same nature which are distinguishable from each other only by their intensity and the forms in which they manifest themselves. ${ }^{84}$ The prohibition is broad: it covers formal agreements, as well as informal communication, decisions and concerted practices.

81 Treaty on the Functioning of the European Union (consolidated version 2016), OJ C 202, 7.6.2016

82 Van Bael, I.; Bellis, J. - F., Competition Law of the European Community, Kluwer Law International, Hague, 2005, p. 27

83 Article 101(1) TFEU. This particularly refers to agreements which

(a) directly or indirectly fix purchase or selling prices or any other trading conditions;

(b) limit or control production, markets, technical development, or investment;

(c) share markets or sources of supply;

(d) apply dissimilar conditions to equivalent transactions with other trading parties, thereby placing them at a competitive disadvantage;

(e) make the conclusion of contracts subject to acceptance by the other parties of supplementary obligations which, by their nature or according to commercial usage, have no connection with the subject of such contracts

84 Case C-49/92 P, Commission v. Anic Partecipazioni, EU:C:1999:356, para. 131. See also Opinion of AG Szpunar in Case C-74/14, Eturas UAB and Others v. Lietuvos Respublikos konkurencijos taryba, EU:C:2015:493, para. 30 
Article 101 TFEU prohibits common conduct by competitors that infringe the existing or potential competition, and in the end, consumers. Collusive agreements and practices are very attractive, because they potentially bring more profit than any competitor would be able to gain through individual conduct. They primarily aim at excluding other competitors from the market, thus opening the possibility for price increase and additional profit. ${ }^{85}$

A meeting of minds is necessary to form an agreement:

" $t \mathrm{t}]$ he concept of an agreement within the meaning of Article [101(1)] of the Treaty, as interpreted by the case-law, centres around the existence of a concurrence of wills between at least two parties, the form in which it is manifested being unimportant so long as it constitutes the faithful expression of the parties' intention" ${ }^{86}$

It is irrelevant if agreement is considered legally binding under national law, ${ }^{87}$ or if it is in writing or oral..$^{8}$

The important thing is to discover the parties' true intent. ${ }^{89}$ Proving the existence of a will to collude may be one of the biggest obstacles in establishing new forms of collusion, where the use of advanced digital tools is involved..$^{90}$ It has to be shown that there was a meeting of minds between competitors at some point.

85 Pošćić, A., Zabranjeni sporazumi u europskom pravu tržišnog natjecanja, Zbornik Pravnog fakulteta Sveučilišta u Rijeci, vol. 32, no. 1, 2011, pp. 319-347, p. 321

86 Case T-41/96 Bayer AG v. Commission of the European Communities, EU:T:2000:242, para. 69

87 Joined Cases 209 - 215 and 218/78 Heintz van Landewyck SARL and others v. Commission of the European Communities, EU:C:1980:248, para. 85 - 86; Case 123/83 Bureau national interprofessionnel du cognac v. Guy Clair, EU:C:1985:33, para 22; Case C-277/87 Sandoz prodotti farmaceutici SpA v. Commission of the European Communities, EU:C:1990:6

88 See, e.g. 77/129/EEC: Commission Decision of 21 December 1976 relating to a proceeding under Article 85 of the EEC Treaty (IV/28.812 Theal/Watts), OJ L 39, 10.02.1977, p. 19-27 and case 28/77 Tepea BV v. Commission of the European Communities, EU:C:1978:133, para. 41. See also Bailey, David, Article 101(1), in: David Bailey, Laura Elizabeth John (eds.), Bellamy \& Child, European Union Law of Competition, $8^{\text {th }}$ Ed., Oxford University Press, Oxford, 2018, p. $108 \mathrm{ff}$.

89 See Joined Cases 209 - 215 and 218/78 Heintz van Landewyck SARL and others v. Commission of the European Communities, EU:C:1980:248, para. 86

90 Participation at meetings where anti-competitive positions were expressed was usually considered sufficient proof of collusive intent, but undertakings could have attempted to prove that they did not have anti-competitive intentions if their position was clearly made known to other participants. See C-204/00 P, C-205/00 P, C-211/00 P, C-213/00 P, C-217/00 P and C-219/00 Aalborg Portland A/S et al. v. Commission of the European Communities, EU:C:2004:6, para. 81 and further. Given that algorithms are making participation at meetings redundant, there will have to be some other proof of communication or tacit acquiescence to establish intent. This will be especially difficult in cases of parallel use of identical algorithms which are commercially available on the market 
Concerted practice differs from agreement in the manner in which the mutual intent is manifested, and later, proved. There is no proof of mutual contacts, but the conduct of competitors deviates from the usual conditions in the market. ${ }^{91}$

The category of concerted practice aims to catch all anticompetitive practices which cannot be subsumed under the definition of agreement or decisions of association of undertakings. Common intent is the element which exists both in agreements and concerted practices. However, in agreements, intent is realized through legally binding form, whereas in concerted practices the latter is missing. ${ }^{22}$ It is sometimes difficult to find a clear distinction between an agreement and a concerted practice, but apart from the difficulties associated with providing proof, it is not important whether an agreement or some form of tacit concerted practice exists. All these "agreements" are anticompetitive and they can hardly be justified by exceptions contained in Article 101(3) TFEU.

A concerted practice comprises three constituent elements: first, concertation between undertakings, secondly, conduct on the market and, thirdly, a causal link between the two. ${ }^{93}$ Coordination and cooperation are constituent elements of a concerted practice within the meaning of Article 101(1) TFEU. ${ }^{94}$

It is well known and established in case law that
"[...] the concept of a concerted practice refers to a form of coordi- nation between undertakings which, without being taken to the stage where an agreement properly so-called has been concluded, know- ingly substitutes for the risks of competition practical cooperation between them." 95

Textbook examples of concerted practices include exchange of information about prices, discounts, sale and other data ${ }^{96}$ concerning conditions and methods of sale, which facilitate concertation and create market conditions which deviate from

91 Vaughan, D. et al., EU Competition Law: General Principles, Richmond Law \& Tax Ltd., Richmond, 2006, p. 62

92 Odudu, O., The Boundaries of EC Competition Law. The Scope of Article 81, Oxford University Press, Oxford, 2006, p. 72

93 Opinion of AG Szpunar in Case C-74/14, Eturas UAB and Others v. Lietuvos Respublikos konkurencijos taryba, EU:C:2015:493, para. 39

94 Case C-194/14 P, AC Treuhand AG v. European Commission, EU:C:2015:717, para. 32

95 Case 48/69, Imperial Chemical Industries Ltd. $v$ Commission of the European Communities, ECLI:EU:C:1972:70, para. 64

96 See more in Butorac Malnar, V.; Pecotić Kaufman H.; Petrović, A., Pravo tržišnog natjecanja, Pravni fakultet Sveučilišta u Zagrebu, Zagreb, 2013, p. 143 ff. 
normal circumstances and present risk for competition. In this manner, competitors can consolidate their positions in the market. ${ }^{97}$

It is difficult to differentiate between situations in which undertakings intelligently adapt to the behaviour of their competitors and those where they act with the knowledge about their competitors' conduct. Economic operators have the right to adapt themselves intelligently to the existing and anticipated conduct of their competitors, as long as they independently determine the policy which they tend to adopt in the internal market. ${ }^{98}$ This means that there should not be

"[...] any direct or indirect contact between such operators, which is such as either to influence the conduct on the market of an actual or potential competitor or to disclose to such a competitor the course of conduct which the operator concerned himself has decided to adopt on the market or which he contemplates adopting, where the object or effect of such contact is to create conditions of competition which do not correspond to the normal conditions of the market in question, regard being had to the nature of the products or services offered, the size and number of the undertakings and the volume of the said market." 99

In other words, every competitor is free to change his prices, taking into account the present or foreseeable conduct of his competitors. However, in so doing, competitors are prohibited from cooperating to determine a coordinated course of action in relation to price increase. ${ }^{100}$

Both legal doctrine and case law consider that intent, or some kind of conscious behaviour, is essential for the collusion to exist. ${ }^{101}$ It will have to be established that the participating undertaking intended to contribute by its own conduct to the common objectives pursued by all the participants and that it was aware of the actual conduct planned or put into effect by other undertakings in pursuit of

97 Joined Cases 40 - 48, 50, 54 - 56, 111, 113 and 114/73 Coöperatieve Vereniging "Suiker Unie" UA and others v. Commission of the European Communities, EU:C:1975:174, para. 26-27

98 Case C-609/13 P, Duravit AG and Others v European Commission, EU:C:2017:46, para. 71; Case C-194/14 P, AC-Treuhand AG v European Commission, EU:C:2015:717, para. 32

99 Case C-609/13 P, Duravit AG and Others v European Commission, EU:C:2017:46, para. 72; Case C-49/92 P, Commission v Anic Partecipazioni, EU:C:1999:356, para. 117

100 Case 48/69, Imperial Chemical Industries Ltd. v. Commission of the European Communities, EU:C:1972:70, para. 118

101 Joined Cases C-89/85, C-104/85, C-114/85, C-116/85, C-117/85 and C-125/85 to C-129/85 89/85, A. Ahlström Osakeyhtiö and others v. Commission of the European Communities, EU:C:1993:120, para. 71; Case 48/69, Imperial Chemical Industries Ltd. v. European Commission of the European Communities, EU:C:1972:70; Ezrachi; Stucke, op. cit., note 9, p. 234 
the same objectives or that it could reasonably have foreseen it and that it was prepared to take the risk. ${ }^{102}$ Passive participation may also constitute infringement. ${ }^{103}$

\subsection{Parallel behaviour and the use of pricing algorithms}

Parallel behaviour is legitimate and may occur without any element of even tacit coordination. However, even though parallel behaviour should not be identified with concerted practice, it can be a strong evidence pointing to the existence of a concerted practice or collusive parallel behaviour, if it leads to conditions of competition which do not correspond to the normal conditions of the market, having regard to the specific features of the market in question: the nature of the products, the size and number of the undertakings, and the volume of the market. ${ }^{104}$ In conducting market analysis, it is examined whether there are certain deviations from predictable conduct and the one which is under review. Establishing parallel conduct by itself is not sufficient, and further economic analyses are needed, whereby the predictability of future conduct of a competitor is especially important. ${ }^{105}$ Crucial element is some form of mental consensus, but also some form of reciprocity. Parallel behaviour which leads to stabilisation of prices which would otherwise not be possible and to consolidation of the existing positions to the detriment of other competitors and consumers may be evidence of concertation.

This is exactly what could happen with the use of pricing algorithms. Application of new technologies, however, has made it more difficult to prove collusive parallel behaviour. Pricing algorithms are developed by third parties, such as IT developers. Other service providers, such as consultants may be involved and facilitate concertation, even though competitors on a relevant market may never meet or exchange communication. Third parties, especially IT developers, are not competitors on the relevant market. In its judgment in case AC-Treuhand, ${ }^{106}$ the court found that a consultancy firm played an essential role in infringements of

\footnotetext{
102 Case C-194/14 P, AC-Treuhand AGv European Commission, EU:C:2015:717, para 30; Case C-49/92 P, Commission v. Anic Partecipazioni, EU:C:1999:356, para. 86 and 87; Joined Cases C-204/00 P, C-205/00 P, C-211/00 P, C-213/00 P, C-217/00 P and C-219/00 P, Aalborg Portland and Others v. European Commission, , EU:C:2004:6, para. 83

103 Case C-194/14 P, AC-Treuhand AG v European Commission, EU:C:2015:717, para. 31; Joined Cases C-189/02 P, C-202/02 P, C-205/02 P to C-208/02 P and C-213/02 P, Dansk Rorindustri and Others v. European Commission, EU:C:2005:408, para. 142 and 143

104 Case 48/69, Imperial Chemical Industries Ltd. v. Commission of the European Communities, EU:C:1972:70, para. 66

105 Joined Cases C-89/85, C-104/85, C-114/85, C-116/85, C-117/85 and C-125/85 to C-129/85 89/85, A. Ahlström Osakeyhtiö and others v. Commission of the European Communities, EU:C:1993:120, para. 64 and 65

106 Case C-194/14 P, AC-Treuhand AG v European Commission, EU:C:2015:717
} 
competition by organising and participating at a number of meetings, collecting and supplying to the producers of heat stabilisers data on sales on the relevant markets, offering to act as a moderator in the event of tensions between those producers and encouraging the latter to find compromises, for which it received remuneration. Even though there was no direct interaction between competitors, horizontal collusion may still be found to exist under two conditions: indirect communication via third party and absence of explicit response. The context of interaction must be such that the addressee may be deemed to appreciate that the illicit initiative comes from a competitor or at least is also communicated to a competitor, who will rely on mutual action, even in the absence of response. ${ }^{107}$

This case law does not resolve the concertation issues in 'real' algorithmic collusion cases. If self-learning algorithms themselves control prices and facilitate swift adaptation to changed market conditions, can algorithmic collusion occur and be proven even without explicit human intervention or influence? Ezrachi and Stucke warn of the risks associated with downplaying the effects of algorithmic tacit collusion and the negative impact it may have on consumers and competition. ${ }^{108}$

\section{POSSIBLE DEVELOPMENTS}

More empirical evidence is needed to show the impact of algorithms on price-fixing and competition under actual market conditions. ${ }^{109}$ The use of algorithms has the potential to significantly alter the structure of the markets. In order to neutralise that potential, it is necessary to revise competition rules, and amend them if required, most notably concerning the burden of proof and liability of third parties for cartels. However, the risks associated with premature regulation should not be underestimated, as it may compromise market development.

We are living in the world of virtual competition. It should be examined from a wider perspective, which entails numerous ethical and social dilemmas involving relations between humans and machines. The question is, can law ascribe responsibility to competitors for operation of machines? ${ }^{110}$ Setting the boundaries of legitimate actions is a challenge for regulators and legislators. Many factors will have to be taken into account, from machine programming, over the levels of protection to their objectives. The issue that is relevant for the future is the degree

\footnotetext{
107 Case C-194/14 P, AC-Treuhand AG v European Commission, EU:C:2015:717, para. 51

108 Ezrachi, Stucke, op. cit., note 9, p. 217 ff.

109 Ezrachi; Stucke, op. cit., note 2, p. 25

110 Loc. cit.
} 
of control humans exercise over artificial intelligence. Humans are programming initial algorithms, independently set the moment from which they will apply and are able to turn off the machine. However, during that time, the machine can operate and adapt its behaviour in various ways. It can alter market structure and decrease competition. The question is, from which moment the algorithm's author is responsible for the operation of the machine? It is an unpredictable surrounding, that may ultimately result in the decrease of welfare, but only as a consequence of the machine's operation and its aim to achieve efficiency. Is collusion among machines possible? ${ }^{111}$ In the present, these situations are within the boundaries of legality. However, that does not mean that status quo should be preserved. It is time to bring collusive algorithmic price coordination practices out of the "black-letter law's blind spot"112 in plain sight, before they irreversibly alter market structures.

\section{REFERENCES}

\section{BOOKS AND ARTICLES}

1. Bailey, David, Article 101(1), in: David Bailey, Laura Elizabeth John (eds.), Bellamy \& Child, European Union Law of Competition, $8^{\text {th }}$ Ed., Oxford University Press, Oxford, 2018

2. Baker, J., The Antitrust Paradigm, Restoring a Competitive Economy, Harvard University Press, Cambridge, London, 2019

3. Bathaee, Y., The Artificial Intelligence Black Box and the Failure of Intent and Causation, Harvard Journal of Law \& Technology, vol. 31, no. 2, 2018, pp. 890-93

4. Beneke, F.; Mackenrodt, M., Artificial Intelligence and Collusion, International Review of Intellectual Property and Competition Law - IIC, vol. 50, 2019, pp. 109-134

5. Butorac Malnar, V.; Pecotić Kaufman H.; Petrović, A., Pravo tržišnog natjecanja, Pravni fakultet Sveučilišta u Zagrebu, Zagreb, 2013

6. Castelvecchi, D., The Black Box of AI, Nature, vol. 538, 2016, pp. 20-23

7. Calvano, E. et al., Algorithmic Pricing: What Implications for Competition Policy?, Review of Industrial Organization, vol. 55, no. 1, 2019, pp. 155-171

8. Cormen, T. H. et al., Introduction to Algorithms, $3^{\text {rd }}$ Ed., The MIT Press, Cambridge, London, 2009

9. Ezrachi, A.; Stucke, M. E., Sustainable and Unchallenged Algorithmic Tacit Collusion, Northwestern Journal of Technology and Intellectual Property, vol. 17, issue 2, 2020, pp. 217-260

10. Ezrachi, A.; Stucke, M. E., Artificial Intelligence \& Collusion: When Computers Inhibit Competition, University of Illinois Law Review, vol. 2017, no. 5, 2017, pp. 1775 - 1810

111 Harrington, Jr, J. E., Developing Competition Law for Collusion by Autonomous Artificial Agents, Journal of Competition Law \& Economics, vol. 14, no. 3/18, p. 333

112 See Mehra, op. cit., note 4, p. 1351: "Black-letter law's blind spot when it comes to independent price coordination - that is, without overt acts such as communication or the adoption of facilitating practices_-may become a cloaking device behind which algorithmic price coordination can readily hide." 
11. Ezrachi, A.; Stucke, M.E., Virtual Competition: The Promise and the Perils of the Algorithm-Driven Economy, Harvard University Press, Harvard, 2016

12. Heinemann, A.; Gebicka, A., Can Computers Form Cartels? About the Need for European Institutions to Reverse the Concertation Doctrine in the Information Age, Journal of European Competition Law \& Practice, vol. 7, no. 7/16, pp. 431-444

13. Harrington, Jr, J. E., Developing Competition Law for Collusion by Autonomous Artificial Agents, Journal of Competition Law \& Economics, vol. 14, no. 3/18., pp. 331-363

14. Krausová; A., EU Competition Law and Artificial Intelligence: Reflections on Antitrust and Consumer Protection Issues, The Lawyer Quarterly, vol. 9, no. 1/19, p. 79

15. Mehra, S. K., Antitrust and the Robo-Seller: Competition in the Time of Algorithms, Minnesota Law Review, vol. 100, 2016, pp. 1323-1375

16. Odudu, O., The Boundaries of EC Competition Law. The Scope of Article 81, Oxford University Press, Oxford, 2006

17. Pošćić, A., Europsko pravo tržišnog natjecanja i interesi potrošača, Narodne Novine, Zagreb, 2014

18. Pošćić, A., Zabranjeni sporazumi u europskom pravu tržišnog natjecanja, Zbornik Pravnog fakulteta Sveučilišta u Rijeci, vol. 32, no. 1/2011, pp. 319-347

19. Van Bael, I.; Bellis, J. - F., Competition Law of the European Community, Kluwer Law International, Hague, 2005

20. Vaughan, D. et al., EU Competition Law: General Principles, Richmond Law \& Tax Ltd., Richmond, 2006

\section{EU LAW}

1. European Commission, Artificial Intelligence for Europe, $\operatorname{COM(2018)~} 237$ final, Brussels, 25.4.2018

2. European Commission, Final Report on the E-Commerce Sector Inquiry, COM(2017) 229 final, Brussels, 10.5.2017

3. European Commission, White Paper on Artificial Intelligence - A European approach to excellence and trust, $\operatorname{COM}(2020) 65$ final, Brussels, 19.2.2020

\section{WEBSITE REFERENCES}

1. Bundeskartellamt, Autorité de la Concurrence, Algorithms and Competition, 2019, [https:// www.bundeskartellamt.de/SharedDocs/Publikation/EN/Berichte/Algorithms_and_Competition_Working-Paper.pdf?_blob=publicationFile\&v=5], accessed 02. May 2020

2. Card, Dallas, The "Black Box" Metaphor in Machine Learning, 2017, [https://towardsdatascience.com/the-black-box-metaphor-in-machine-learning-4e57a3a1d2b0], accessed 02. May 2020

3. European Commission, Competition policy for the digital era, A Report by Crémer, J., de Montjoye, Y. - A., Schweitzer, H., 2019, [https:/lec.europa.eu/competition/publications/ reports/kd0419345enn.pdf], accessed 02. May 2020 
4. Gal, M., Algorithms as Illegal Agreements, Berkeley Technology Law Journal, vol. 34, 2019, pp. 67-118 [https://btlj.org/data/articles2019/34_1/02_Gal_Web.pdf], accessed 25. June 2020

5. Ittoo, A.; Petit, N., Algorithmic Pricing Agents and Tacit Collusion: A Technological Perspective, in: Jacquemin, H.; De Streel, A. (eds.), L'intelligence artificielle et le droit, Bruxelles: Larcier, 2017, pp. 241-256. Available also at SSRN [https://ssrn.com/abstract=3046405] or [http://dx.doi.org/10.2139/ssrn.3046405], accessed 25. June 2020

6. McAfee, R.P.; te Velde, V., Dynamic Pricing in the Airline Industry, [https://mcafee.cc/Papers/PDF/DynamicPriceDiscrimination.pdf], accessed 02. May 2020

7. Monopolkommission, Wettbewerb 2018. XXII. Hauptgutachten der Monopolkommission gemäß $\$ 44$ Abs. 1 Satz 1 GWB, para. 169 and further, [https://www.monopolkommission. de/images/HG22/HGXXII_Gesamt.pdf], accessed 02. May 2020

8. OECD, Algorithms and Collusion: Competition Policy in the Digital Age, 2017, p. 11 [http:// www.oecd.org/daf/competition/Algorithms-and-colllusion-competition-policy-in-the-digital-age.pdf], accessed 02. May 2020

9. Oxera, Algorithmic Competition, 2018, [https://ec.europa.eu/competition/information/ digitisation_2018/contributions/oxera/oxera_algorithmic_competition.pdf], accessed 02 . May 2020

10. Schwalbe, U., Algorithms, Machine Learning, and Collusion, Journal of Competition Law \& Economics, vol. 14, issue 4, 2018, pp. 568-607, available at SSRN [https://ssrn.com/ abstract=3232631] or [http://dx.doi.org/10.2139/ssrn.3232631], accessed 25. June 2020

11. Thomas, S., Harmful Signals - Cartel Prohibition and Oligopoly Theory in the Age of Machine Learning, Journal of Competition Law \& Economics, vol. 15, issue 2-3, June/September 2019, pp. 159-203; available also at SSRN [https://ssrn.com/abstract=3392860] or [http:// dx.doi.org/10.2139/ssrn.3392860], accessed 25. June 2020

12. Vestager, M., Algorithms and competition, speech, Bundeskartellamt 18th Conference on Competition, Berlin, 16 March 2017 [https://ec.europa.eu/commission/commissioners/2014-2019/vestager/announcements/bundeskartellamt-18th-conference-competition-berlin-16-march-2017_en], accessed 20. June 2020

13. Zdzieborska, M., Brave New World of 'Robot' Cartels?, Kluwer Competition Law Blog, March 7, 2017, [http://competitionlawblog.kluwercompetitionlaw.com/2017/03/07/brave-newworld-of-robot-cartels/], accessed 02. May 2020 